\title{
PENDIDIKAN AGAMA HINDU BERBASIS BUDAYA DALAM MEMBENTUK KARAKTER PESERTA DIDIK
}

\author{
Roy Wentas \\ Institut Agama Hindu Negeri Tampung Penyang Palangkaraya \\ bawiayahfda@gmail.com
}

\begin{abstract}
Riwayat Jurnal
Artikel diterima : 8 Juli 2019

Artikel direvisi $\quad: 25$ Juli 2019

Artikel disetujui : 1 Agustus 2019
\end{abstract}

\begin{abstract}
Abstrak
Kemajuan ilmu pengetahuan dan teknologi cenderung memunculkan perbedaan antara generasi yang lebih tua dan generasi yang lebih muda. Karena itu mempelajari orientasi nilai di kalangan anak muda dan peserta didik, terutama sikap keberagaman yang tentunya penting. Melatih generasi muda sebagai generasi berikutnya adalah tanggung jawab bersama antara keluarga, komunitas dan negara bangsa. Pendidikan Agama dapat menjalankan dan mempraktikkan ajaran-ajaran agama Hindu sehingga membentuk akhlak dan moral mulia. dalam kitab suci, Bhagavadgita menyatakan dua kecenderungan mempengaruhi karakter manusia, sifat-sifat semua devata (daivi sampat) dan sifat-sifat raksasa (asuri sampat). Kedua kecenderungan ini secara langsung atau tidak langsung akan membentuk karakter manusia. Pesatnya perkembangan ilmu pengetahuan dan teknologi dewasa ini telah mempengaruhi karakter anak-anak, yang dihadapkan pada tantangan berat. Mengajar anak-anak harus kemudian diarahkan untuk memperkuat moral mereka. Mengenai itu, perlu norma neo-tradisional yang didasarkan pada asal-usul tradisional. Pendidikan Hindu dapat menjadi agen normatif yang membangun setiap karakter Indonesia modern melalui kearifan lokal mereka yang memotivasi anak-anak. Pada tingkat instrumental, nilai-nilai utama yang akan diajarkan adalah otonomi, martabat, kreativitas, moralitas, kebanggaan dan rasa estetika, dan kesadaran demokrasi. Mereka harus melestarikan warisan budaya lokal, termasuk bahasa dan seni, sambil mengadaptasi tren global. Sebagai pendidik, guru di sekolah dan juga orang tua di rumah harus menjadi panutan yang tanggung jawab dan disiplinnya dipatuhi.
\end{abstract}

Kata kunci: Pendidikan Karakter Hiduisme, Pendidikan Agama Hindu, Peserta Didik,

\section{Pendahuluan}

Pembangunan bidang pendidikan merupakan salah satu pembangunan aspek sosial dan budaya serta merupakan bagian yang sangat penting dan tidak dapat ditawar lagi dan menjadi suatu keharusan dalam rangka meningkatkan dan mengembangkan sumber daya 
manusia yang memiliki kemampuan/ketrampilan yang tinggi, moral dan budi pekerti yang luhur serta cerdas dan kreatif. Perkembangan ilmu pengetahuan dan teknologi serta peradaban manusia, memaksa kita sebagai bagian masyarakat dunia, turut mengejar dan mengembangkan diri agar tidak tertinggal jauh dibelakang. Dalam rangka mengejar ketertinggalan ini sebagai bangsa harus terus menerus meningkatkan diri dalam segala aspek bidang kehidupan baik ideologi, politik, ekonomi, sosial, budaya, pertahanan, keamanan, hukum, dan teknologi melalui pembangunan. Hal ini dimaksudkan agar mutu sumber daya manusia Indonesia dapat bersaing dengan bangsa-bangsa lain di dunia. Kemajuan suatu bangsa dan negara sangat ditentukan oleh mutu sumber daya manusia (SDM).

Mutu SDM tidak hanya dilihat dari penguasaan ilmu pengetahuan dan teknologi saja, melainkan juga karakter atau perilakunya. Untuk memenuhi SDM yang memiliki kompetensi dan karakter diperlukan sistem pendidikan yang baik. Undang-Undang No 20 Tahun 2003 Tentang Sistem Pendidikan Nasional pada Pasal 3, menyebutkan bahwa Pendidikan Nasional berfungsi mengembangkan kemampuan dan membentuk karakter serta peradaban bangsa yang bermartabat dalam rangka mencerdaskan kehidupan bangsa. Pendidikan Nasional bertujuan untuk berkembangnya potensi peserta didik agar menjadi manusia yang beriman dan bertaqwa kepada Tuhan Yang Maha Esa, berakhlak mulia, sehat, berilmu, cakap, kreatif, mandiri, dan menjadi warga negara yang demokratis serta bertanggung jawab.

Pendidikan di Indonesia belum dipandang sebagai sebuah proses kultural yang lebih menekankan pada pembentukan cara berpikir yang holistik. Yang tercipta kemudian adalah generasigenerasi yang mudah berada dalam kebimbangan dalam pesatnya kemajuan perkembangan modernitas Capra (2000). Seiring dengan perkembangan ilmu pengetahuan dan teknologi, serta memasuki era globalisasi dan era informasi menuntut semua bidang kehidupan untuk mengaktualisasikan diri dengan kebutuhan agar tidak ketinggalan zaman. Penyesuaian-penyesuaian yang dilakukan dalam bidang pendidikan demi meningkatkan kualitas pendidikan diantaranya memberlakukan kurikulum tingkat satuan pendidikan, sertifikasi tenaga pendidikan, mengadakan evaluasi hasil belajar secara nasional, mengadakan pelatihan-pelatihan kepada para pendidik (Elmubarok, 2009). Kalangan pemerintah termasuk masyarakat nampaknya sudah terseret dalam pola pikir bahwa pendidikan semata-mata merupakan proses makanis yang berorientasi pada pola pikir yang mengedepankan pragmatisme. Konsekwensi logis dari era globalisasi \& era informasi yang meniadakan batas-batas lokal, regional dan international,adalah mempercepat pengaruh budaya, pola hidup serta perilaku yang tidak sesuai dengan budaya nasional. 
Fakta menunjukan di masyarakat telah terjadi dekadensi moral, penyalahgunaan narkoba, penurunan iman dan takwa, disharmonisasi antar warga masyarakat, kriminal serta meningkatnya korupsi dan perilaku sex yang menyimpang. Hal inilah yang menjadi tantangan bagi dunia pendidikan khususnya pendidikan agama. Memperhatikan hal tersebut di atas mengenai dilemanya proses pendidikan, mengenai kontribusi pendidikan agama termasuk pendidikan agama dalam menopang perilaku menyimpang peserta didik. Pembentukan kembali karakter peserta didik merupakan sebuah hal yang cukup sulit namun penting untuk dirilis kembali. Sebab dewasa ini pendidikan agama Hindu dihadapkan pada persimpangan jaman globalisasi yang cukup membuat resah masyarakat. Oleh karena demikian tuntutan akan pendekatan multidisiplin dalam pembelajaran agama Hindu penting digerakan kembali demi kepentingan persatuan nasional dan nilai-nilai kebangsaan.

\section{Pembahasan}

\subsection{Pendekatan Multikultur dalam Pendidikan Nasional}

Pendidikan multikultural mengandung arti bahwa proses pendidikan yang diimplementasikan pada kegiatan pembelajaran di satuan pendidikan selalu mengutamakan unsur perbedaan sebagai hal yang biasa, sebagai implikasinya pendidikan multikultural membawa peserta didik untuk terbiasa dan tidak mempermasalahkan adanya perbedaan secara prinsip untuk bergaul dan berteman dengan siapa saja tanpa membedakan latar belakang budaya, suku bangsa, agama, ras, maupun adat istiadat yang ada.

Pendidikan agama Hindu harus memiliki acuan nilai kultural dalam penataan aspek legal. Tata nilai itu sendiri bersifat kompleks dan berjenjang mulai dari jenjang nilai ideal, nilai instrumental, sampai pada nilai operasional. Pada tingkat ideal, acuan pendidikan agama Hindu adalah pemberdayaan untuk kemandirian dan keunggulan. Pada tingkat instrumental, nilai-nilai yang penting perlu dikembangkan melalui pendidikan agama Hindu adalah otonomi, kecakapan, kesadaran berdemokrasi, kreativitas, daya saing, estetika, kearifan, moral, harkat, martabat dan kebanggaan. Pada tingkat operasional, pendidikan agama Hindu harus menanamkan pentingnya kerja keras, sportifitas, kesiapan bersaing, dan sekaligus bekerjasama dan disiplin diri (Geriya, 1991).

Pendidikan multikultural sebenarnya sudah tertuang dalam filsafat pendidikan Indonesia yaitu filsafat Pancasila yang mengakui keberagaman bangsa dalam satu wadah. Multikulturalisme merupakan suatu perkembangan yang relatif paling baru dalam khazanah ilmu pengetahuan sosial dan budaya (humaniora), terutama pasca pemikiran liberalisme dalam bidang ilmu politik. Multikulturalisme terus berkembang sesuai dengan derasnya 
perubahan sosial-budaya yang dihadapi oleh umat manusia khususnya di dalam era dunia terbuka dan era demokratisasi kehidupan. Menurut Fay (dalam Parsudi Suparlan, 2003:1) multikulturalisme merupakan sebuah ideologi yang mengakui dan mengagungkan perbedaan dalam kesederajatan, baik secara individual maupun secara kebudayaan. Oleh karena itu, multikulturalisme seharusnya tidak dipahami semata-mata sebagai sekumpulan perbedaan belaka yang dapat dijumlahkan dan disatusatukan secara kuantitatif, tetapi sebaliknya multikulturalisme adalah sebuah kualitas dan bukan entitas, yang secara mutlak mensyaratkan adanya, empati, solidaritas dan keadilan sosial (Budiman, 2003:2).

Pada dasarnya multikulturalisme bukan sekadar wacana tetapi ideologi yang harus diperjuangkan sebagai landasan pendidikan yang mengakui dan mau membina keanekaragama dalam kehidupan. Akan tetapi sebagai sebuah ideologi multikulturalisme tidak dapat berdiri terpisah dari ideologi-ideologi lainnya; sebaliknya, multikulturalisme justru membutuhkan seperangkat bangunan konsep-konsep untuk memahaminya. Berbagai konsep yang berkaitan dengan multikulturalisme antara lain: demokrasi, keadilan dan hukum, nilai-nilai budaya dan etos kerja, kebersamaan dalam perbedaan yang sederajat, suku bangsa dan kesukubangsaan, kebudayaan etnik, keyakinan keagamaan, ungkapanungkapan budaya, domain privat dan publik, hak budaya komuniti, dan konsepkonsep lainnya yang relevan (Fay dalam Suparlan, 2003: 4). Hal ini terkait dengan adanya paling tidak tiga faktor yang mendorong berkembang-luasnya wacana pemikiran multikulturalisme, yaitu: HAM (Universal Declaration of Human Rights yang diprakarsai oleh PBB pada tahun 1948), globalisme, dan proses demokratisasi.

Model pendidikan yang kiranya dapat diterapkan di Indonesia, dalam mengembangkan pendidikan multikultural, di samping melalui penyempurnaan kurikulum dan bahan ajar, termasuk juga penataran guru atau dosen dan hal ini dapat dilaksanakan oleh guru dosen pemegang mata pelajaran/mata kuliah Pendidikan Kewarganegaraan atau Pendidikan Moral Pancasila, di samping sudah tentu para guru agama, guru bimbingan dan penyuluhan (BP) dan sangat ideal bilamana pendidikan multikultural ini dapat diintegrasikan peda semua mata pelajaran dan oleh karena itu semua guru di sekolah hendaknya terlibat dalam proses belajar mengajar (PBM) pendidikan multikultural ini. Tidak kalah pentingnya adalah orang tua peserta didik/ mahapeserta didik yang menumbuhkembangkannya di rumah (dalam keluarga) dan para tokoh agama dan tokoh masyarakat dalam mengambil peranan, menjadi teladan dalam memajukan pendidikan multikultural ini. Media massa, khususnya TV sangat berperanan dalam menunjang pendidikan multikultural ini. Hal-hal yang perlu 
ditekankan dalam pendidikan multikultural ini antara lain:

Cinta dan bhakti kepada tanah air, tumpah darah tempat dilahirkan, jangan membenci atau merugikan tanah air sendiri dan tanah air orang lain. Menumbuhkan apresiasi terhadap berbagai agama dan budaya dengan mengembangkan sikap toleransi yang sejati. Hormati semua agama dengan rasa hormat yang sama, setiap agama adalah jalan menuju Tuhan Yang Maha Esa. Demikian pula memberikan apresiasi dan penghormatan yang sama terhadap berbagai budaya, utamanya budaya daerah di Nusantara. Cintai semua orang tanpa membeda-bedakan latar belakang etnis, suku, agama dan profesi orang, karena semua manusia apa pun latar belakangnya adalah satu komunitas yang tunggal.Pelihara kebersihan dan ketentraman rumah tangga dan lingkungan sosial, maka kesehatan dan kebahagiaan masyarakat akan dapat diwujudnyatakan.

Jadilah dermawan, jangan buat sesuatu yang menjadikan seseorang menjadi pengemis. Bantulah orang yang memerlukan sesuai kebutuhan dan menjadikan mereka mandiri. Jangan menggoda seseorang dengan menawarkan/memberi hadiah atau merendahkan diri dengan menerima suap. Jangan membenci, dengki, irihati dengan alasan apa pun kepada siapa pun juga. Jangan bergantung pada siapapun, usahakan untuk melaksanakan sendiri sebanyak mungkin, walaupun seseorang kaya raya dan memiliki banyak pembantu, tetapi pelayanan masyarakat (seva) agar dilaksanakan langsung sendiri. Jadilah pelayan bagi diri sendiri dan orang lain. Jangan sekali-kali melanggar hukum yang berlaku di negara kita. Patuhilah peraturan perundangundangan yang berlaku. Jadilah warga negara teladan. Cintailah Tuhan Yang Maha Esa, dan segenap ciptaan-Nya dan jauhilah dosa dan perbuatan buruk.

Dengan demikian, pendidikan multikultural sangat relevan dilaksanakan dalam mendukung proses demokratisasi, dimana pada pendidikan multikultural terdapat beberapa hal terkait mengenai, pengakuan hak asasi manusia, tidak adanya diskriminasi dan diupayakannya keadilan sosial. Selain itu, dengan pendidikan multikultural ini dimungkinkan seseorang dapat hidup dengan tenang di lingkungan kebudayaan yang berbeda dengan yang dimilikinya. Bila semua komponen bangsa Indonesia terpanggil untuk membangun pendidikan multikultural ini, maka pada saatnya bangsa Indonesia akan menjadi bangsa yang benar-benar dikenal sebagai bangsa yang sangat ramah, jujur, dermawan dan mendapatkan penghargaan, sejajar dengan bangsa-bangsa yang telah jauh lebih maju dari bangsa kita. Will Kymlicka (2003:134) mengutip pendapat Margalit dan Raz (1990: 447-9) menyatakan: "Apabila suatu kebudayaan secara umum tidak dihormati, maka martabat dan rasa harga diri para anggotanya akan juga terancam". Pendapat Margalit dan Raz ini dapat saja terjadi di Indonesia, bila bangsa ini tidak 
segera mengantisipasinya dan satu cara di antaranya adalah dengan mengembangkan pendidikan multikultural, menegakkan nilai-nilai etika dan moralitas dalam membangun masa depan bangsa Indonesia. Ke depan pendidikan etika dan moralitas, disamping plularisme beragama dan multikulturalisme, serta patriotisme dan nasionalisme hendak-nya lebih mendapatkan perhatian dari pemerintah.

\subsection{Pendidikan Agama Hindu sebagai Penanaman Nilai Budaya}

Agama Hindu sebagai suatu sistem keyakinan dapat menjadi bagian dari suatu sistem nilai yang ada dalam kebudayaan peserta didik, menjadi pendorong sekaligus pengendali bagi tindakan-tindakan para peserta didik tersebut agar tetap sesuai dengan nilainilai agama dan kebudayaannya (Sukadi, 2001:2). Dalam pengertian seperti ini maka wilayah peran dan fungsi pendidikan agama Hindu dalam proses pendidikan yang kongkret-historis adalah membudayakan prilaku peserta didik yang bernilai budaya.

Pendidikan agama Hindu adalah jiwa dari proses pendidikan umatnya dalam mendukung muncul prilaku normatif yang mendukung proses pemberdayaan dan pembudayaan Sehingga pendidikan agama begitu pula dengan pendidikan agama Hindu dalam kebudayaan dapat berfungsi sebagai (1) sebagai sistem yang mengatur tindakan peserta didik yang berbudaya moral, (2) memantapkan, meresapkan perasaan- perasaan, motivasi-motivasi secara kuat, menyeluruh dan bertahan lama dalam diri peserta didik, (3) memformulasikan sekumpulan tata tertib dalam diri peserta didik (Geertz, 1977). Beranjak akan keberadaan pendidikan agama Hindu sebagai sistem nilai budaya menjadi tuntunan normatif tetapi juga nyata memberikan dorongan atau motivasi bagi kehidupan peserta didik, bagaimana setiap peserta didi memiliki sifat dan prilaku yang megandung nilai-nilai luhur. Dalam kondisi seperti itu tentu tidak dapat dipungkiri bahwa pendidikan agama Hindu tidaklah steril mempengaruhi dan dipengaruhi oleh keseluruhan sistem budaya dalam proses pendidikan. Satu masalah yang penting kemudian muncul dari interelasi pendidikan agama Hindu dengan unsur budaya pembelajaran adalah pendidikan agama Hindu tidaklah steril dari aspek perubahan, karena tidak ada pendidikan dan kebudayaan yang tidak mengalami perubahan.

Sekolah sebagai salah satu tempat menyelenggarakan pendidikan agama Hindu harus dapat melestarikan budaya lokal dengan tetap mengikuti tren budaya global yang berkembang, misalnya bahasa daerah, gamelan, dan tarian tradisional perlu dilestarikan sebagai warisan budaya bangsa. Tetapi tidak dapat kita pungkiri pula bahwa penguasaan bahasa asing, band, dan modern dance harus juga dipelajari sebagai budaya global yang disukai remaja saat ini. Karena itu, nuansa religius di sekolah dengan pelaksanaan 
sembahyang/ TriSandhya sebelum pembelajaran yang dilaksanakanharus dijadikan aktivitas rutin. Membudayakan salam dan saling menegur dengan bahasa yang ramah harus menjadi fenomena yang biasa.

\subsection{Membenah Mutu Pendidikan Agama Hindu yang mulai merosot}

Revitalisasi sejarah pendidikan bangsa memang mengalami pasang surut dalam perkembangannya. Beranjak dari fenomena dan kenyataan seperti itu maka penting sekali dilakukan penataan kembali mengenai penanaman ajaran agama Hindu yang utuh kepada peserta didik dalam dunia pembelajaran yang mikro. Pendidikan Agama Hindu merupakan salah satu mata pelajaran yang ikut menentukan laju perkembangan ilmu pengetahuan dan teknologi (IPTEK), oleh karena itu penyelenggaraan kegiatan pendidikan tidak bisa lepas dari peranan pendidikan agama Hindu. Hal ini dikarenakan proses pendidikan agama Hindu dijadikan sebagai sebuah media dalam mengembangkan nilai spiritual dan etika terhadap peserta didik yang telah mengalami kemerosotan. Dengan demikian peserta didik diharapkan mampu membangun segenap potensi dalam dirinya yaitu menghayati dan merefleksikan pengetahuan yang dimiliki ke dalam cara berpikir, ucapan dan tindakan sehari-hari dalam lingkungan sekolah sebagai lingkungan terkecil dalam menggali pengetahuan.
Di dalam Undang-Undang Dasar 1945 pasal 31 tentang pendidikan menyebutkan antara lain pemerintah memajukan ilmu pengetahuan dan teknologi dengan menjunjung tinggi nilai nilai agama dan persatuan bangsa untuk kemajuan peradaban serta kesejahteraan umat manusia. Pendidikan agama memiliki kedudukan sangat penting dalam membentuk akhlak mulia dan moral peserta didik. Hal tersebut disebabkan oleh pendidikan agama termasuk pendidikan agama Hindu merupakan bagian integral dalam membentuk perilaku peserta didik secara nyata (Tanu, 2008:13). Dengan hasil sain dan teknologi berbagai temuan didapatkan, jarak waktu dapat diperpendek, berbagai macam penyakit bisa ditanggulangi, teknologi informasi berkembang pesat dan lain sebagainya, menyebabkan hidup manusia makin meningkat. Kemudahan yang didapatkan tersebut tidak akan berarti apa-apa, apabila tidak didasari oleh nilai, etika dan moral yang kokoh dalam penggunaannya. Hal tersebut bisa akan menjadi bumerang pada manusia itu sendiri.

Menata proses pendidikan termasuk dalam ranah pembelajaran agama Hindu adalah hal yang sangat mendesak untuk dilakukan, walaupun kenyataannya diketahui sulit. Pada hakikatnya proses penataan kembali proses pembelajaran agama Hindu termasuk pelajaran yang membangun prilaku peserta didik yang lain diperlukan karena hadirnya sejumlah perubahan dalam dimensi pendidikan, yang beberapa diantaranya sangat 
fundamental dan tidak pernah diramalkan sebelumnya. Dunia bergerak ke masa depan dengan dinamis, dan dalam proses itu banyak nilai masa lalu yang tidak tepat lagi dengan konteks perkembangan jaman begitu pula dengan nilai normatif dalam pembelajaran agama Hindu.

Kemajuan ilmu pengetahuan dan teknologi yang pesat seperti dewasa ini mempengaruhi pola kehidupan anak terutama perkembangan sikap dan kepribadiannya, karena kehidupan pada abad ini anak dihadapkan pada tantangantantangan yang berat. Kenyataan seperti adanya kenakalan pada anak, kesulitan para orang tua untuk mengatur anaknya, kurangnya minat belajar anak dan yang lainnya. Membina seorang anak hendaknya ditekankan pada pembentukan nilai moralnya, agar kualitas anak lebih berharga, mampu menghadapi tekanan serta rongrongan dari luar dan dalam dirinya, seseorang tidak cukup membina anak dengan kecukupan materi, apalagi kalau hal itu dilakukan berlebih-lebihan dan berakibat merusak jiwa anak (Muharyono, 2008). Hal tersebut disebabkan karena memang perubahan perkembangan pola pemikiran di era milenial ini mempengaruhi struktur kehidupan manusia termasuk para peserta didik, menyebabkan sebagian peserta didik mengalami disorientasi nilai. Dalam tingkat tertentu hal tersebut juga mempengaruhi dunia pendidikan termasuk pendidikan agama Hindu, yang saat ini dirasakan betul tentang merosotnya moral peserta didik, ketidak seimbangan kecerdasan emosional peserta didik dengan kecerdasan intelektual dan kecerdasan spiritual yang dimilikinya. Sebab ilmu dan pengetahuan yang tidak dibarengi dengan tingkat keimanan dan moralitas yang tinggi menyebabkan pendidikan kehilangan esensinya sebagai wahana memanusiakan manusia. Terkait dengan perubahan jaman tersebut, untuk bisa membangun paragidma pendidikan dalam lingkungan dunia baru (global) ini, diperlukan hadirnya neotradisional norm yaitu nilai-nilai baru yang berakar pada nilai-nilai tradisional (asli) dan dalam perkembangan dan perubahan nilai dapat disebut dengan dynamic integrated norm yaitu suatu perubahan nilai yang dilakukan dalam kehidupan tetapi masih bersumber dan terintegrasi dengan nilai aslinya.

Krisis moral dan etika, harus diakui telah mengkondisikan kesenjangan di masyarakat. Masyarakat mulai mempertanyakan efektivitas pendidikan agama di lembaga pendidikan. Ditengarai ada permasalahan mendasar yang layak dipecahkan guna optimalisasi pencapaian sasaran pendidikan. Keberadaan kurikulum pendidikan agamapun mulai ditimang-timang. Ternyata, terbatasnya alokasi waktu hanya empat jam dalam seminggu dinilai oleh berbagai kalangan sebagai salah satu penyebabnya. Pemuatan materi pelajaran yang tidak sesuai dengan perkembangan peserta didik, pengetahuan yang disampaikan sangat teoritis, telah membuat membiasnya pencapaian sasaran. Banyak orang memiliki kecerdasan yang luar biasa dan prestasi yang gemilang secara 
akademik namun tidak memberikan manfaat yang berarti dalam lingkungan masyarakatnya, bahkan menjadi racun yang sangat membahayakan bagi eksistensi budaya dan nilai-nilai kemanusiaan karena iman dan moralitasnya rendah. Tidak sedikit kasus amoral terjadi yang dilakukan oleh anakanak usia sekolah maupun oleh para orang dewasa, baik melalui layar televisi maupun media masa.

Fenomena tersebut terjadi karena kesenjangan antara penanaman nilai agama dengan pengetahuan. Hal tersebut mengingat bahwa ilmu dan agama pernah memiliki hubungan yang tidak harmonis di masa lalu, ketika golongan rohaniawan mendominasi seluruh aspek kehidupan manusia, tidaklah dapat dipungkiri. Karena itu, perkembangan ilmu pengetahuan dan teknologi mengalami hambatan. Tetapi, di jaman modern ini, sejak jaman pencerahan Enstein menyatakan bahwa ilmu tanpa agama buta, agama tanpa ilmu lumpuh (Suriasumantri, 1985). Mencermati suatu fenomena mengenai rendahnya sikap disiplin peserta didik yang sangat berimbas kepada keberadaan materi agama Hindu. Dewasa ini banyak sekali ditemukan sikap peserta didik yang sangat arogan dalam dunia pendidikan sekolah. Moral dan sikap displin peserta didik di sekolah sangat rendah yang dibuktikan oleh berbagai bukti pelanggaran peserta didik seperti: (1) Peserta didik tidak menyapa guru dengan salam yang seyogyanya; (2) cara berpakaian dan tutur kata peserta didik jauh dari kode etik seorang pelajar; (3) sering membuat kerusuhan bila ada jam kosong dan bahkan terjadi pertengkaran antar peserta didik; (4) sering membolos, terlambat dan bahkan tidak masuk sekolah tanpa alasan yang pasti. Kenyataan tersebut bila dicermati dari hakikat tujuan pendidikan sangatlah pahit, namun guru agama yang membawa misi dan pesan moral tidaklah dapat bekerja sendiri.

Mengenai contoh sebuah isu menurun moral peserta didik di sekolah disebabkan oleh beberapa hal yang semestinya tidak boleh terjadi. Adapun faktor yang menyebabkan hal tersebut, yaitu : (1) kurang kesinergian dan peran aktif semua guru di lingkungan sekolah untuk peduli dalam membentuk karakter peserta didik; (2) analisis latar belakang peserta didik banyak sekali yang menjadikan sekolah tersebut sebagai sebuah pelarian; (3) tes penerimaan peserta didik tidak memperhatikan psikologis anak sehingga setelah mulai bersekolah peserta didik memiliki sifat sekehendak hati; (4) pendidikan agama sebagai modal pembentukan nilai dan karakter peserta didik, mendapatkan posisi yang terbelakang dalam artian materi pelajaran agama lain lebih penting. Kenyataan seperti hal tersebut yang menghambat proses pembelajaran, yang akhirnya menyebakan suatu dekadensi moral peserta didik.

Terjadinya dekadensi moral yang sangat mengkhawatirkan menjadi indikasi betapa pendidikan formal sesungguhnya bisa divonis gagal membangun sebuah 
peradaban yang lebih baik. Ketika kesadaran mulai merasuki relung-relung pemikiran mereka yang memiliki kepedulian terhadap nasib generasi penerus, segera melirik pendidikan yang menekankan ajaran-ajaran agama sebagai solusi alternatif. Di dalam UndangUndang Dasar 1945 pasal 31 tentang pendidikan menyebutkan antara lain pemerintah memajukan ilmu pengetahuan dan teknologi dengan menjunjung tinggi nilai nilai agama dan persatuan bangsa untuk kemajuan peradaban serta kesejahteraan umat manusia. Pendidikan agama memiliki kedudukan sangat penting dalam membentuk akhlak mulia dan moral peserta didik. Hal tersebut disebabkan oleh pendidikan agama termasuk pendidikan agama Hindu merupakan bagian integral dalam membentuk perilaku peserta didik secara nyata (Tanu, 2008:13). Pendidikan agama Hindu diharapkan dapat dipahami dengan baik oleh peserta didik, agar dengan pemahaman ini peserta didik dapat mengaktualisasikan nilai-nilai agama yang diperoleh dalam praktek kehidupannya.

Guru diharapkan dapat menyampaikan materi secara komunikatif, edukatif dan persuasif sehingga tujuan yang diharapkan dapat terpenuhi. Berdasarkan uraian diatas, maka Pendidikan agama Hindu memiliki peran dalam penanggulangan perilaku yang kurang baik melalui interaksi edukatif yang dilakukan antara guru dan peserta didik. Pengembangan pendidikan lebih berorientasi pada kompetensi peserta didik, dan difokuskan pada kemampuan life skill peserta didik. Kompetensi dasar pendidikan agama Hindu adalah; peserta didik memiliki sradha dan bhakti kepada Ida Sang Hyang Widhi Wasa, berakhlak mulia (berbudi pekerti luhur) yang tercermin dalam perilaku sehari-hari dalam hubungannya sebagai mahkluk ciptaan Tuhan, sesama manusia, dan alam sekitar mampu membaca dan memahami kitab suci Weda, serta mampu menjaga kerukunan intern dan antar umat beragama. Pendidikan agama Hindu juga diarahkan untuk membangun kualitas mental pribadi peserta didik yang cerdas, terampil dan memiliki sikap keberagamaan, peka terhadap perubahan perilaku di masyarakat, komitmen terhadap nilai-nilai dan prinsip-prinsip hidup secara harmonis dan kreatif dalam masyarakat yang pluralistk, kepedulian terhadap lingkungan dan berkarya sesuai dengan swadarmanya (Tanu, 2008 : 27).

Pendidikan Agama Hindu sebagai bagian dari sistem pendidikan nasional harus memiliki kontribusi dalam rangka mengentaskan dekadensi moral dan efek negatif lainnya yang memang merupakan ranah garapan dari bidang ini sejajar dengan pendidikan agama lainnya di Indonesia, pendidikan moral dan pendidikan seni, sosial dan budaya. Gejala merosotnya moral peserta didik disebabkan oleh kurangnya pemahaman nilai normatif agama dalam kepribadian peserta didik. Selain itu, peserta didik belum siap melakukan aktivitas keagamaan secara rutinitas sebagaimana 
diamanatkan dalam kitab suci weda, yakni proses pembelajaran belum dipandang sebagai kewajiban moral oleh peserta didik (Tanu, 2008:192).

Sehubungan dengan hal tersebut penting sekali dilakukan penggalian nilainilai baru dalam penyelenggaraan agama, disamping diadakan kesenergian dalam bebagai dengan pelajaran budaya dan budi pekerti dalam kehidupan peserta didik (Tanu, 2011). Hal tersebut mengingat problem seperti dekadensi moral yang muncul dalam pembelajaran agama di sekolah disebabkan adanya pemisahan peserta didik dalam proses pembelajaran agama. Fenomena tersebut dapat menimbulkan sikap berlebihan terhadap ajaran agama yang dianut oleh peserta didik (Listia, 2007). Mencermati tentang problematik pembelajaran termasuk pembelajaran agama Hindu harus mampu dikaji secara bersama-sama oleh komponen pendidikan. Moral peserta didik mengalami dilematis ditengah pemerosotan jaman yang membuatnya menentukan pilihan dalam melangkah. Proses salah langkah tersebut yang menyebabkan interprestasi prilaku peserta didik menjadi buram dan merusak tatanan ranah dan nilai pendidikan yang ada. Dengan demikian penting sekali diadakan pembenahan mengenai nilai pendidikan bangsa melalui pembentukan karakter budaya peserta didik.

\subsection{Pembentukan Karakter Peserta Didik Pendidikan Agama Hindu} Pendidikan agama merupakan salah satu aspek penting dalam upaya pembentukan perilaku peserta didik. Karena itu, setiap wacana pendidikan agama selalu menarik perhatian publik. Melalui pendidikan agama, kepribadian peserta didik dibentuk dan diarahkan sehingga dapat mencapai derajat kemanusiaan sebagai makhluk berbudaya. Untuk itu, idealnya pendidikan agama tidak hanya sekedar sebagai transfer ilmu pengetahuan dan keterampilan (transfer of knowledge and skill) tetapi lebih dari itu adalah transfer perilaku (transfer of attitude). Di sekolah upaya pembentukan kepribadian peserta didik secara lebih intens dilakukan melalui pendidikan agama. Diharapkan, pendidikan agama mampu membentengi peserta didik dari berbagai pengaruh negatif lingkungan, sekaligus dapat menjadi agen sosial (social agent) menuju masyarakat yang lebih berperadaban (civil society). Namun demikian, belakangan masyarakat mulai mempertanyakan efektivitas penyelenggaraan pendidikan agama dalam konteks pembentukan perilaku peserta didik. Fenomena dalam masyarakat memperlihatkan bahwa secara umum hasil pembelajaran pendidikan agama Hindu (PAH) di sekolah dewasa ini belum memuaskan banyak pihak, dan bahkan dinilai gagal. Pelajaran agama serta pesan-pesan moral yang disampaikan oleh guru di depan kelas, tidak mampu menjiwai setiap gerak langkah peserta didik dalam kehidupan masyarakatnya. Hal ini tentunya, disebabkan oleh keringnya pembelajaran yang dirasakan peserta didik, materimateri pelajaran agama masih 
berorientasi pada pengajaran agama yang bersifat kognitif dan sebagai pelajaran tambahan yang harus dihapal. Disamping itu kurang keintegrasian pendidikan agama Hindu dengan mata pelajaran lain, sehingga nilai moral tidak dapat meresap dalam kepribadian peserta didik secara utuh (Tanu, 2008:207).

Diantara indikator yang sering dikemukakan, bahwa dalam kehidupan masyarakat, masih dijumpai banyak kasus tindakan masyarakat yang bertentangan dengan ajaran agama. Adanya kekerasan dan keberingasan yang dilakukan di kalangan pemuda, pelajar dan mahapeserta didik, masih marak diberitakan dalam media massa. Demikian juga perilaku maksiat, kasus kehamilan di luar nikah di kalangan peserta didik-peserta didik sekolah serta banyaknya para peserta didik sekolah terlibat dalam penggunaan narkoba, memperlihatkan adanya penghayatan peserta didik belum memadai terhadap nilai-nilai ajaran agama. Agama memiliki peran yang amat penting dalam kehidupan umat manusia. Agama menjadi pemandu dalam upaya mewujudkan suatu kehidupan yang bermakna, damai dan bermartabat. Menyadari bahwa peran agama amat penting bagi kehidupan umat manusia maka internalisasi agama dalam kehidupan setiap pribadi menjadi sebuah keniscayaan, yang ditempuh melalui pendidikan baik pendidikan di lingkungan keluarga, sekolah maupun masyarakat. Pendidikan Agama dimaksudkan untuk membentuk peserta didik menjadi manusia yang beriman dan bertaqwa kepada Tuhan Yang maha Esa dan berakhlak mulia serta peningkatan potensi spiritualnya. Akhlak mulia mencakup etika, budi pekerti, dan moral sebagai perwujudan dari pendidikan Agama. Peningkatan potensi spiritual mencakup pengenalan, pemahaman, dan penanaman nilai-nilai keagamaan dalam kehidupan individual ataupun kolektif kemasyarakatan. Peningkatan potensi spiritual tersebut pada akhirnya bertujuan pada optimalisasi berbagai potensi yang dimiliki manusia yang aktualisasinya mencerminkan harkat dan martabatnya sebagai makhluk Tuhan. Pendidikan Agama Hindu adalah usaha yang dilakukan secara terencana dan berkesinambungan dalam rangka mengembangkan kemampuan peserta didik untuk memperteguh sradha dan bhakti terhadap Tuhan Yang Maha Esa/ Sang Hyang Widhi Wasa sesuai dengan ajaran Weda, dengan tetap memperhatikan penghormatan terhadap agama lain dalam hubungan kerukunan antar umat beragama dalam masyarakat untuk mewujudkan persatuan nasional.

Peningkatan mutu pendidikan diarahkan untuk meningkatkan kualitas manusia Indonesia seutuhnya melalui olah hati, olah pikir, olah rasa dan olah raga agar memiliki daya saing dalam menghadapi tantangan global. Peningkatan relevansi pendidikan dimaksudkan untuk menghasilkan lulusan yang sesuai dengan tuntutan kebutuhan berbasis potensi sumber daya alam Indonesia. Peningkatan efisiensi manajemen pendidikan dilakukan melalui 
penerapan manajemen berbasis sekolah dan pembaharuan pengelolaan pendidikan secara terencana, terarah, dan berkesinambungan. Pendidikan yang idealnya dapat meningkatkan kualitas hidup dan kesejahteraan serta berupaya merekonstruksi suatu peradaban adalah salah satu kebutuhan asasi yang dibutuhkan oleh setiap manusia. Hal ini juga merupakan pekerjaan wajib yang harus diemban oleh negara agar dapat membentuk masyarakat yang memiliki pemahaman dan kemampuan untuk menjalankan fungsi-fungsi kehidupan selaras dengan tugasnya serta mampu mengembangkan kehidupannya menjadi lebih baik dari setiap masa ke masa. Kesemuanya itu tidak luput dari peran ilmu agama sebagai pembentuk karakteristik dan mental peserta didik yang berbudi luhur. Sehingga, penguasaan terhadap ilmu pengetahuan, teknologi, aspek-aspek materi (hasil-hasil teknologi) dan kemajuan-kemajuan lainnya merupakan sesuatu yang harus disadari oleh peserta didik sebagai kebutuhan dan kewajiban yang harus selalu dilaksanakan dalam menjaga keharmonisan kehidupan.

Sehubungan dengan dunia pendidikan, maka peranan pendidikan agama Hindu dituntut menjadi agen pembentuk karakter bangsa yang dimulai dari karakter peserta didiknya, melalui membentuk nilai-nilai modern yang tetap bercirikan Indonesia dengan berbagai kearifan lokalnya (Atdmaja, 2011). Untuk itulah pengaruh pendidikan moral dan etika yang diberikan kepada peserta didik penting untuk diintegrasikan dengan pelajaran agama Hindu. Maka dari itu diperlukan pendidik agama Hindu yang berkemampuan mempersonafikasikan nilai-nilai etik kemanusiaan dan keagamaan dalam pembelajaran. Meskipun tidak berarti bahwa seorang pendidik adalah seorang malaikat, namun dinamika kehidupannya menunjukkan wajah ketulusan untuk membantu peserta didik. Pendidikan agama Hindu pada dasarnya memiliki prinsip yang sama dengan pendidikan lain, hanya saja tanggung jawab moral yang dipikul para pendidik agama termasuk agama Hindu lebih berat dalam memanusiakan manusia. Serangkaian usaha membangun moral peserta didik dibutuhkan sebuah suasana baru dalam pendidikan yaitu suasana kekeluargaan, kebaikan hati, empati, cinta kasih dan penghargaan terhadap peserta didik, tidak ada pendidikan tanpa dasar cinta kasih. Pengembangan nilai-nilai sathya (kesetiaan/kejujuran), dharma (kebajikan), shanti (kedamaian), dan ahimsa (tanpa kekerasan). Seperti yang diajarkan dalam Bhagawadgita "advesta sava bhutanam", janganlah membenci siapapun dan apapun dalam ciptaan, karena Tuhan ada pada setiap nama dan wujud. Bila setiap peserta didik memiliki rasa cinta kasih yang memenuhi dirinya, maka Tuhan akan sangat mengasihinya. Antara pendidik dengan peserta didi semestinya ada hubungan yang harmonis dan penuh kasih, bukan hanya sekedar hubungan yang formal dalam lembaga pendidikan. Seorang peserta didik harus 
dengan tulus menghormati gurunya, mentaatinya tanpa merasa terpaksa melainkan menjalani kewajiban itu dengan tulus dan ikhlas. Taitriya Upanisad mengajarkan:Matru deva bhavo, pitru devo bhavo, acharya devo bhavo, atiti devo bhavo.Hormatilah ibumu, hormatilah ayahmu, hormatilah gurumu, hormatilah tamu sebagai perwujudan Tuhan di muka bumi ini. Dengan demikian pendidikan agama Hindu yang diselenggarakan hendaknya dapat membantu peserta didik untuk berkepribadian merdeka, sehat fisik, sehat mental, cerdas, serta menjadi anggota masyarakat yang berguna (Pandit, 2005). Manusia merdeka adalah seseorang yang mampu berkembang secara utuh dan selaras dari segala aspek kemanusiannya dan mampu menghargai dan menghormati kemanusiaan setiap peserta didik.

Proses pembentukan karakter peserta didik yang berorientasi pada pemahaman ajaran agama Hindu selain yang telah diuraikan di atas, ada empat cara yang bisa dijadikan pedoman, yaitu melalui jalan Bhakti Yoga, Karma Yoga, Jnana Yoga, dan Raja Yoga. Dari keempat jalan tersebut yang palingmendektai diaplikasikan dalam proses pembentukan perilaku peserta didik dapat dilakukan melalui KarmaYoga, dan Bhakti Yoga. Melalui Karma yoga pesertadidik dapat memahami ajaran agama dari perbuatan yang nyata. Lewat pola ini, peserta didik diajarkan atau diberikan pendidikan agama dengan jalan memberikan contoh- contoh yang nyata berdasarkan atas Weda, sebab agama Hindu tidak harus melalui teori semata namun bisa juga dilakukan dengan tindakan-tindakan nyata yang mencerminkan nilai-nilai keagamaan. Berikutnya melalaui Bhakti Yoga pada tahap ini, peserta didik diberikan tata krama bersikap sesuai ajaran agama, seperti hormat dan bhkati kepada ajaran guru yaitu guru rupaka adalah bhkati kepada orang tua di rumah, guru pengajian hormat dan bhkati kepada bapak/ibu guru yang memberikan pendidikan di sekolah, guru wisesa hormat dan bhakti kepada pemerintah dan yang paling utama adalah hormat dan bhakti kepada guru sejati yaitu guru swadyaya (Ida Sang Hyang Widhi Wasa).

Terkait dengan tugas yang dipikul oleh para pendidik yang di dalam termasuk pendidik agama Hindu diperlukan serangkaian prinsip untuk dijadikan landasan dalam pelaksanaan reformasi prinsip pendidikan agama Hindu. Salah satu prinsip yang masti dibahwa oleh para pendidik yaitu mampu melakukan proses pembudayaan dan pemberdayaan peserta didik yang berlangsung sepanjang hayat, di mana dalam proses tersebut harus ada pendidik yang memberikan keteladanan dan mampu membangun kemauan, serta mengembangkan potensi dan kreativitas peserta didik. Budaya keteladanan, dan kedisiplinan dari para pendidik baik pendidik di sekolah maupun orang tua peserta didik harus terus dikembangkan dan memiliki tanggung jawab untuk memajukan sekolah dalam membina 
disiplin peserta didik (Sulhan, 2010). Rendahnya moral pendidikan kita saat ini disebabkan oleh lemahnya komitmen warga sekolah dalam mewujudkan budaya sekolah. Harapan yang sekarang harus terpenuhi dalam menatata moralitas pendidikan adalah membudayakan nilainilai agama sesuai dengan budaya peserta didik. Pembentukan karakter peserta didik memberikan sebuah pengertian untuk menentukan apakah hubungan pembelajaran dengan pencapaian tujuan pendidikan agama Hindu, memberikan makna, untuk memfokuskan perencanaan pembelajaran dan menuju keadaan yang tepat atau cocok dengan sosio-kultural dan sosio religius yang merupakan pilarpilar penting terwujudnya idealitas pembelajaran pendidikan agama Hindu.

Dalam penanganan kendala perilaku peserta didik, guru perlu mengetahui sebab-sebab peserta didik berperilaku yang tidak sesuai dengan tujuan kurikulum pendidikan agama Hindu. Guna terwujudnya karakter peserta didik yang sesuai dengan tujuan pendidikan agama Hindu, maka pendidik harus berupaya melakukan berbagai pendektan seperti : Pertama, pendekatan kesadaran yaitu bersifatmenggugah hati nurani, suara hati menjadi pengawas dirinya sendiri penerapannya melalui pengajaran sopan santun dan penanaman nilai-nilai agama Hindu. Kedua, pendekatan bersifat ajakan yaitu suatu pendekatan untuk memantapakan keyakinan dan menumbuhkembangkan serta mening-katkan motivasi dalam mencapai tujuan pendidikan agama
Hindu. Ketiga, pendekatan etika melalui pendektan ini peserta didik diajarkan untuk memahami tentang perbuatan baik dan buruk (subha,asubha karma) dan penanaman perilaku dalam kehidupan sehari-hari yang berlandaskan dharma. Keempat, pendekatan sosial keagamaan, pendekatan ini adalah upaya meningkatkan perilaku peserta didik yang berlandaskan nilai-nilai pendidikan agama Hindu melalui kegiatan sosial keagamaan yang mencakup tiga hal yaitu dama (pengendalian diri), dana (mewajibkan pemberian dengan didasari hati yang ikhlas/lascarya), karuna (kasih sayang atau welas asih terhadap sesama). Peserta didik diajarkan berderma dengan sradha dan rasa simpati yang tinggi (mudita). Amal kedermawanan adalah sifat yang jauh lebih besar artinya dari harta kekayaan. Jika tidak dipergunakan untuk berdana punia, maka secara sepiritual tidak kekayaan materi tidak ada nilainya.

\section{Penutup}

Pemikiran manusia membuat arus perkembangan zaman semakin kian menonjol, sebuah sebuah bukti timbul teknologi dalam system kehidupan. Namun di balik hal tersebut terdapat sisi gelap dari proses global yang melanda kehidupan. Sebagai sebuah subsistem yang sangat kecil yaitu dalam dunia pembelajaran sangat dirasakan sekali modernisasi diwarnai dan dimaknai tidak dengan semestinya sehingga melahirkan berbagai penyimpangan prilaku dan merosotnya moral peserta didik. 
Pendidikan agama Hindu sebagai sebuah subsistem pendidikan nilai dihadapakan pada dilematis di tengah persimpangan jaman, yang akhirnya menuntut keras campur tangan bersama dalam membentuk moral peserta didik. Proses kesinergian pendidikan agama Hindu dengan pelajaran lain merupakan sebuah strategi dalam membentuk karakter pendidikan bangsa Indoneisa, dengan mengacu pada nilai budaya kehidupan peserta didik. Melalui pendidikan agama, kepribadian peserta didik dibentuk dan diarahkan sehingga dapat mencapai derajat kemanusiaan sebagai makhluk berbudaya.

Pendidikan agama Hindu mendorong peserta didik untuk dapat menjalankan ajaran agamanya dalam kehidupan sehari-hari, dan menjadikan agama sebagai landasan etika dalam kehidupan pribadi, keluarga, masyarakat, bangsa dan negara mengingat suksesnya anak-anak dalam mengikuti pelajaran agama tidak bisa diukur dari perolehan angka semata melainkan juga bisa dilihat dari sikap dan perilakunya. Oleh karena itu jika semua pihak konsekuen dengan tujuan pendidikan nasional bahwa selain mencerdaskan kehidupan bangsa, juga membetuk mental spiritual seharusnya pendidikan agama mendapat porsi yang sewajarnya.

\section{DAFTAR PUSTAKA}

Atmajda, I N Bawa. 2001. PendidikanKarakterBangsa.

Singaraja: Undhiksa.
Budiman, $\quad$ Manneke. 2003. 'JatidiriBudaya dalam Masyarakat Multikultural'. Makalah dalam Seminar Pendidikan Multikultural dan Revitalisasi Hukum Adat dalam Perspektif Budaya, diselenggarakan Dep. Kebudyaandan Pariwisata, Bogor: tanggal 18-20 Desember 2003.

Capra, F. 2000. Titik Balik Peradaban:Sains, Masyarakat, danKebangkitan Kebudayaan. Yogyakarta: Yayasan BentangBudaya.

Elmubarok, Z. 2009. Membumikan Pendidikan Nilai,Mengumpulkan yang Terserak, Menyambung yang Putus, dan Menyatukan yang tercerai. Bandung: Alfabeta.

Geerts, C. 1977. Penjaja dan Raja: Perubahan Sosialdan Modernisasi Ekonomi di Dua Kota Indonesia ( S. Supomo: Penterjemah). Jakarta:Gramedia.

Geriya, I.W. 1991. Peranan Agama Hindu dalamTransformasi Budaya. Denpasar: InstitutHindu Dharma. Hasibuan, S.P. Malayu. 1996. ManajemenPengertian dan Masalah Dasar. Jakarta:Gunung Agung.Kymlicka, Willy, 2003. Kewargaan Multikultural. Jakarta, Pustaka LP3ES Indonesia.

Listia, dkk. 2007. Problematik Pendidikan Agamadi Sekolah. Yogyakarta: Institut Dian.

Maharyono, HS, SB. 2008. Pendidikan Karakter Bangsa Indoneisa. 
Educare, nomor 7/5 Oktober2008.

Halaman 22-17-21.

Pandit, B. 2005. Pemikiran Hindu PokokPokokPemikiran Agama Hindu dan Filsafatnya.Surabaya: Paramita.

Sukadi. 2011. Peran Ilmu Sosial dan Humaniora dalam Pembelajaran Agama. Makalah seminar di Pascasarjana IHD Negeri Denpasar. Tidak diterbitkan.

Sulhan, N. 2010. Pendidikan Berbasis KarakterSinergi antara Sekolah dan Rumah dalam Membentuk Karakter Anak. Surabaya:Jaringpena.

Suparlan, Parsudi. 2003. 'Мепијu Masyarakat Indonesia yang Multikultural'. Makalah dalam Seminar Pendidikan Multikulturaldan Revitalisasi Hukum Adat dalam Perspektif Budaya, diselenggarakanDepartemen Kebudyaan dan Pariwisata, Bogor, tanggal. 18-20 Desember 2003.

Susriasumantri, J.S. 1985. Filsafat Ilmu SebuahPengantar Populer. Jakarta: Sinar Harapan.

Tanu, I Ketut. 2008. Isu-isu Kontemporer Pendidikan Agama Hindu di Sekolah Dasar (perspektif kritis culture studies). Denpasar: SariKhayangan Indonesia.

Titib, I Made. 2003. Teologi dan SimbolSimboldalam Agama Hindu. Surabaya: Paramita. 